\title{
Histopathology of the kidney and seroprevalence of leptospirosis in wild rats in Baghdad Province, Iraq
}

\author{
Abdulkarim Jafar Karim ${ }^{1}$ (i) and Zainab Majid Abbas² (i) \\ 1. Unit of Zoonotic Diseases, College of Veterinary Medicine, University of Baghdad, Baghdad, Iraq; 2. Department of \\ Pathological Analysis, Babylon Technical Institute, Al-Furat Al-Awsat Technical University, Babylon, Iraq. \\ Corresponding author: Abdulkarim Jafar Karim, e-mail: abdalkarem@covm.uobaghdad.edu.iq \\ Co-author: ZMA: zma90@yahoo.com \\ Received: 26-11-2020, Accepted: 19-01-2021, Published online: 17-02-2021
}

doi: www.doi.org/10.14202/IJOH.2021.19-30 How to cite this article: Karim AJ, Abbas ZM (2021) Histopathology of the kidney and seroprevalence of leptospirosis in wild rats in Baghdad Province, Iraq, Int. J. One Health, 7(1): 19-30.

\begin{abstract}
Background and Aim: Leptospirosis, caused by pathogenic leptospires, is a globally emerging infectious disease affecting both humans and animals, which act as reservoirs, with large outbreaks worldwide. The role of rats in dispersing leptospirosis was never investigated in Iraq. Because of the seriousness of the disease and the scarce data regarding this disease in Iraq, this study determines the incidence of leptospirosis in rats and its renal histopathological profile.
\end{abstract}

Materials and Methods: Of 211 captured rats, 82 apparently healthy rats were included in this study. After euthanatizing, $3-5-\mathrm{ml}$ blood was collected by cardiac puncture. Approximately $0.5 \mathrm{~cm}^{3}$ of the kidney was collected for routine histopathology and stained using hematoxylin and eosin (H\&E) and Warthin-Starry (WS) stains. Blood smears were prepared and stained with the WS stain.

Results: All rats (100\%) with different age groups were immunoglobulin G (IgG)-positive, and 90.24\% of them had the IgG against leptospiral antigens in kidney tissues. The juvenile age group had higher IgG levels than other age groups. Considering sex, no significant differences in the overall results were observed. Serum concentrations of blood urea nitrogen and creatinine showed significant increments in the sub-adult and adult IgG- positive groups compared with the IgGnegative groups. No significant alterations were observed in the juvenile group. Using WS stains, 13 and 1 blood smears and 0 and 8 kidney tissues were positive for leptospires in the sub-adult and adult groups, respectively. Microscopical findings of the renal cortex and medulla in the sub-adult IgG-positive group showed hemorrhage, glomerular deterioration, tubular cell degeneration and necrosis with cast formation, periarterial edema, and focal hemorrhage with congestion of peritubular arteries. The adult IgG-positive group revealed deterioration similar to that in the sub-adult group and tended to be chronic. No leptospires were observed using H\&E staining.

Conclusion: IgG-positive carrier rats refer to previously exposed or infected rats. Understanding the risk of transmitting the disease to human and animals through a carrier rat's urine is highly predicted and possible mitigation of zoonotic transmission.

Keywords: histopathology, kidney, leptospirosis, rats, serology.

\section{Introduction}

Wild rats could be found everywhere. Their mobility from sewage to our kitchen serves as a reservoir for many diseases. Rats are responsible for dispersing many diseases to humans, particularly the silent "asymptomatic" disease, and leptospirosis [1,2]. Environmental factors, including humidity and flooding, play a crucial role in the spread of leptospirosis, leading to a higher incidence of this disease in tropical countries. However, because rats are ubiquitous, leptospirosis remains a public health issue even in large cities of both developed and developing countries $[3,4]$. Rats and most animals become infected when exposed to the urine of cohabiting infected rats

Copyright: Karim and Abbas. This article is an open access article distributed under the terms of the Creative Commons Attribution 4.0 International License (http://creativecommons.org/ licenses/ by/4.0/), which permits unrestricted use, distribution, and reproduction in any medium, provided you give appropriate credit to the original author(s) and the source, provide a link to the Creative Commons license, and indicate if changes were made. The Creative Commons Public Domain Dedication waiver (http:// creativecommons.org/ publicdomain/zero/1.0/) applies to the data made available in this article, unless otherwise stated. that carry different serovars. After initial infection, animals act as carriers and continue shedding bacteria into the environment [2,5]. Known risk factors include occupational exposure among farmers, butchers, and sewage workers and swimming in ponds contaminated with animal urine.

Leptospirosis is a serious emerging waterborne fatal bacterial zoonosis. Large outbreaks occur worldwide. A significant morbidity occurs in tropical areas following flooding and excess rainfall [5]. Hence, large outbreaks of leptospirosis are not restricted only to tropical regions [3]. In China, 50 human casualties were reported in 1500 patients infected with leptospirosis during a 10-month follow-up study [6]. Leptospirosis occurs everywhere carrier rats could be found. Dogs, pigs, horses, cattle, rats, mice, mongoose, and sea mammals could be infected [7]. The symptoms of leptospirosis, also known as Weil's disease, usually manifest 7-14 days after being infected and are extremely broad. It is mostly misdiagnosed because of its nonspecific symptoms, including fever, headache, chills, sweating, muscle pain, painful eyes, jaundice, and vomiting. 
Many organs are involved resulting in nephritis, hepatitis, pneumonitis [8,9], meningitis [10], pancreatitis [11], and erythema nodosum [12], and leptospirosis could result in death if not treated promptly [13].

As leptospirosis was recorded in the Middle East, in particular Turkey and Iran [14,15], a limited number of studies have been performed in Iraq to diagnose the disease in farm animals mainly in Baghdad, Mosul, and Nasiriyah Provinces [16-21].

Alternatively, the role of rats in dispersing leptospirosis was never investigated in Iraq. Because of the seriousness of the disease and the scarce data regarding this disease in Iraq, this study determines the incidence of leptospirosis in rats and its renal histopathological profile.

\section{Materials and Methods}

\section{Ethical approval}

All tests and procedures were approved under no. 1569 on January 13, 2015, by the Animal Care and Use Committee of the Faculty of Veterinary Medicine, University of Baghdad.

\section{Study period and location}

This study was conducted at the Unit of Zoonotic Diseases, College of Veterinary Medicine, University of Baghdad from a period extended from May 2015 till the end of August 2016.

\section{Traps}

Small $(28 \mathrm{~cm} \times 10 \quad \mathrm{~cm} \times 10 \quad \mathrm{~cm})$ and large $(35 \mathrm{~cm} \times 15 \mathrm{~cm} \times 15 \mathrm{~cm})$ iron cages were used in this study for capturing rats. Traps, baited with cheese and cucumber, were set in the evening in different sites [22]. Each live trap with captured animal was tagged locality and collected early in the morning. Then, the animals were brought to the laboratory and kept in a big transparent polythene cage that helped to observe their movements for $24 \mathrm{~h}$. Thereafter, the rats were caught from tail, and $0.1 \mathrm{~mL}$ of anesthesia $(9: 1$, ketamine + xylazine per $100 \mathrm{~g}$ rat body weight) was intraperitoneally injected as described by Struck et al. [23].

\section{Animals}

Two hundred and eleven black stray rats (Rattus rattus) were caught from various areas, including old buildings, markets, and garbage bins in the Baghdad Province. The rats were classified into three groups (juvenile, sub-adult, and adult groups) according to body weight $(<100 \mathrm{~g}, 100-150 \mathrm{~g}$, and $>150 \mathrm{~g})$, and the position of the testes (abdominal or scrotal), and status of the vagina (unopened, opened, or scars), as described by Schlafer and Foster [24].

\section{Media, chemicals, and equipment}

All media, chemicals, and equipment used in this study were purchased from certified companies (Sigma-Aldrich and Promega, USA).

\section{Dissection of captured rats}

After euthanatizing, the outer orifices and median dissecting line of each rat were disinfected with $70 \%$ alcohol. Deep pharyngeal swabs in transport media were taken for bacteriological culture, and then, the rats were dissected individually. The abdominal cavity was opened using a sterile disposable blade under a sterile hood.

\section{Specimens collected}

Feces pellets from the rectum and urine from the urinary bladder using a sterile syringe were collected for bacteriological and parasitological investigations [25]. The kidney $(.0 .5 \mathrm{~g})$ was collected under a sterile condition in the hood, placed in a sterile Petri dish, and kept in the deep freeze at $-20^{\circ} \mathrm{C}$ for homogenization. Approximately $0.5 \mathrm{~cm}^{3}$ of the kidney was placed in $10 \%$ formalin buffer phosphate overnight. The following day, the solution was discarded and replaced with fresh formalin buffer saline for prompt fixation and processed for routine histopathological investigation. Slides were stained using hematoxylin and eosin (H\&E) and Warthin-Starry (WS) stains [26,27].

\section{Blood sampling}

After anesthetization, the rats were tested for corneal reflex reaction and toe pinch. The heart was approached easily by laying the rats on their right lateral side. Cardiac puncture was performed using a 5-mL syringe, and 3-5 $\mathrm{ml}$ of blood was collected.

\section{Thin blood smears}

Immediately, thin blood smears were prepared, and the rest of the collected blood was drained into a sterile plain tube and kept in a fridge at $2-4^{\circ} \mathrm{C}$ overnight to allow the samples to clot. The thin blood smears were fixed with $100 \%$ methanol and let dry completely before staining. The thin blood smears were stained using the WS stain for detecting Leptospira [27].

\section{Serum}

Clotted blood kept in a fridge overnight was centrifuged at approximately $3000 \mathrm{rpm}$ for $15 \mathrm{~min}$. Serum was removed and transported to an Eppendorf tube and stored at $-20^{\circ} \mathrm{C}$ until analysis.

Rat Leptospira immunoglobulin G (IgG) enzymelinked immunosorbent assay (ELISA) kit

An assay was performed for detecting serum IgG according to the manufacturer's instructions.

\section{Kidney enzymes}

Serum blood urea nitrogen (BUN) and creatinine concentrations were estimated, according to Gounden et al. [28].

\section{Kidney homogenate}

Homogenates were prepared according to Karim [29].

\section{Statistical analysis}

The results were expressed as mean \pm standard deviation and analyzed using the Chi-square test and one-way analysis of variance. All statistical analyses were performed using Statistical Package for the 
Social Sciences version 22 (IBM Corp., Armonk, NY, USA).

\section{Results}

\section{Captured rats}

Of 211 captured rats, $82(38.86 \%)$ showed negative bacteriological culture and negative parasitological yield. According to Schlafer and Foster [24], the age classes of the rats involved in this study were distributed (Table-1).

\section{ELISA}

Plotted standard curve (Figure-1) shows that optic density above 2.0 yielded zero IgG concentrations. All rats were serum IgG-positive (Table-2) with a wide range shown by a high standard deviation (96.172 \pm 46.475$)$. Alternatively, kidney tissues showed that $90.24 \%$ of the rats had IgG against leptospiral antigens, and the rest $(9.76 \%)$ were IgG-negative.

\section{Effect of age}

All age groups showed that $100 \%$ of the rats were serum IgG-positive. Alternatively, kidney homogenates showed that the rats in the juvenile group had higher IgG concentrations than the other age groups (Table-3).

\section{Gender susceptibility}

Although significant variations in $\operatorname{IgG}$ levels were observed between genders within the same age group, no significant differences in the overall results were observed (Table-4).

Table-1: Classification of captured rats according to age classes.

\begin{tabular}{lccc}
\hline Age class & No. & Male & Female \\
\hline Juvenile & 44 $\mathrm{b}(53.66 \%)$ & 19 & 25 \\
Sub-adult & $2^{\mathrm{a}}(28.05 \%)$ & 13 & 10 \\
Adults & $15^{\mathrm{a}}(18.29 \%)$ & 11 & 04 \\
Total & 82 & 43 & 39 \\
\hline
\end{tabular}

Different superscripts refer to significant differences $(p<0.05)$ between age groups

\section{Kidney function test}

Serum concentrations of BUN and creatinine (Table-5) showed significant increments $(p<0.05)$ in the sub-adult and adult IgG-positive groups compared with the IgG-negative groups. No significant alterations were observed in the juvenile group. The alterations in these parameters increased two-fold in the sub-adult group, and BUN peaked as high as threefold in the adult group, whereas the increment for creatinine was almost eightfold.

Detection of leptospires in blood smears and kidney

Using the WS and H\&E staining, leptospires in blood smears and renal tissues were not detected in the juvenile group (Table-6). However, 13 positive blood smears were infected with leptospires (Figure-2), whereas no bacteria could be detected in the kidneys in the sub-adult group. In the contrary, only eight kidneys stained using the WS stain (Figure-3) and one blood smear showed the presence of leptospires in the adult group.

\section{Histopathology of the kidney}

No specific gross lesion was evident. Microscopical findings of the renal cortex and medulla in the sub-adult

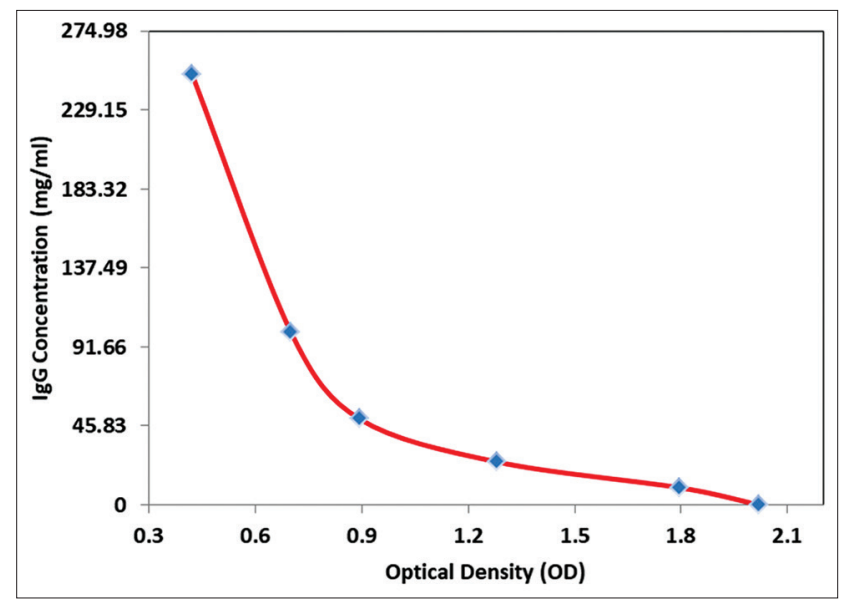

Figure-1: A standard curve showed the optic density versus immunoglobulin $\mathrm{G}$ concentrations.

Table-2: Concentration ( $\mathrm{mg} / \mathrm{mL}$ ) of immunoglobulin $\mathrm{G}$ in serum and kidney homogenate of captured rats.

\begin{tabular}{lccccc}
\hline Parameters & \multicolumn{2}{c}{ Kidney homogenate } & & \multicolumn{2}{c}{ Serum } \\
\cline { 2 - 3 } & Negative & & Negative & Positive \\
\cline { 2 - 3 } & $\mathbf{( n = 8 )}$ & $(\mathbf{n = 7 4 )}$ & & $\mathbf{( n = 0 )}$ & $\mathbf{( n = 8 2 )}$ \\
\hline OD & $2.086 \pm 0.014$ & $1.659 \pm 0.023$ & $\mathrm{Nil}$ & $1.243 \pm 0.017$ \\
Conc. & 0 & $95.172 \pm 50.674$ & & $\mathrm{Nil}$ & $96.172 \pm 46.475$ \\
$\%$ & 9.76 & 90.24 & & 0 & 100 \\
\hline
\end{tabular}

Table-3: Occurrences of immunoglobulin $\mathrm{G}$ in serum and kidney homogenate of captured rats according to age classes.

\begin{tabular}{|c|c|c|c|c|c|}
\hline \multirow[t]{2}{*}{ Age class } & \multirow[t]{2}{*}{$\mathbf{n}$} & \multicolumn{2}{|c|}{ Kidney homogenate } & \multicolumn{2}{|c|}{ Serum } \\
\hline & & Positive n (\%) & Negative $\mathrm{n}(\%)$ & Positive n (\%) & Negative \\
\hline Juvenile & 44 & $42(95.45)^{a}$ & $2(4.55)$ & $44(100)^{a}$ & Nil \\
\hline Sub-adult & 23 & $21(91.30)^{a}$ & $2(8.70)$ & $23(100)^{a}$ & Nil \\
\hline Adults & 15 & $11(73.33)^{\mathrm{b}}$ & $4(26.67)$ & $15(100)^{a}$ & Nil \\
\hline Total & 82 & $74(90.24)$ & $8(9.76)$ & $82(100)$ & 0 \\
\hline
\end{tabular}

Different superscripts refer to significant differences $(p<0.05)$ between age groups 
IgG-positive group showed hemorrhage (Figure-4), glomerular deterioration (Figure-5), tubular cell degeneration and necrosis (Figures-6 and 7) with cast formation (Figure-8), periarterial edema, and focal hemorrhage (Figure-9) with congestion of peritubular arteries (Figure-10). Microscopical findings of the renal cortex in the adult IgG-positive group revealed deterioration similar to that in the sub-adult group (Figures-11-13). No leptospires were observed using H\&E staining. However, bacteria were observed inside the renal tubules using the WS staining method (Figure-3).

\section{Discussion}

\section{Captured rats}

Health status

Among the 211 captured rats, $82(38.86 \%)$ rats showing negative bacteriological culture and negative parasitological yield were included in this study. This action was taken to exclude any pathological effects on the various parameters (kidney function tests and histopathology) planned to be investigated. Wild and laboratory rats are usually prone to be infected with different diseases [30-32]. Although complete coverage of the health status is not fulfilled, $38.86 \%$ of the captured rats were apparently healthy. This ratio conforms to the study by Clement et al. [33] who reported higher rates of apparently healthy rats based on clinical examination only.

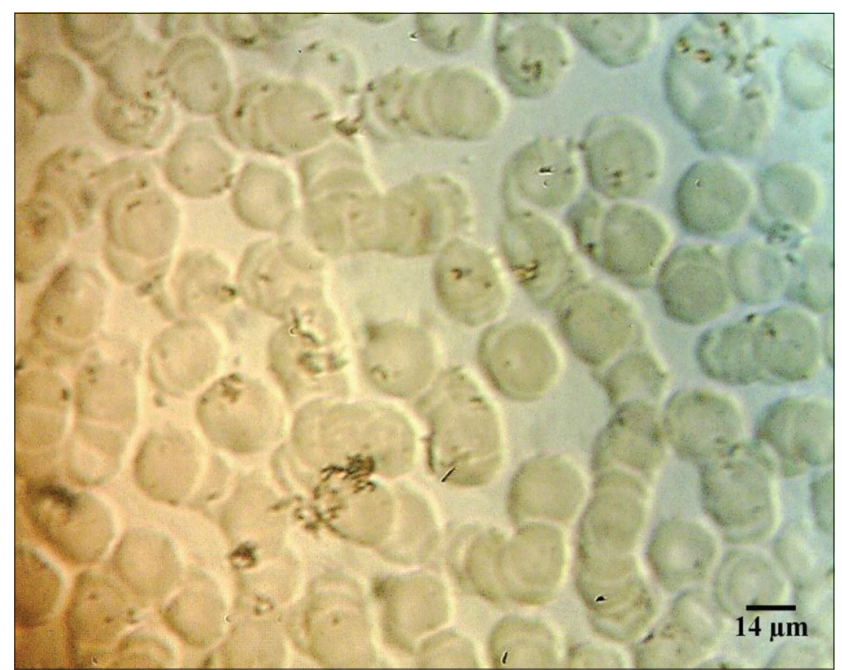

Figure-2: Blood smear of sub-adult immunoglobulin G positive rats. Note the presence of Leptospira (WS stain).

Table-4: Occurrences of immunoglobulin G in serum and kidney homogenate of captured rats according to gender.

\begin{tabular}{|c|c|c|c|c|c|c|c|}
\hline \multirow[t]{2}{*}{ Age class $(\mathbf{N})$} & \multirow[t]{2}{*}{ Immunoglobulin G } & \multicolumn{3}{|c|}{ Kidney homogenate } & \multicolumn{3}{|c|}{ Serum } \\
\hline & & $\mathbf{n}$ & Male & Female & $\mathbf{n}$ & Male & Female \\
\hline \multirow[t]{2}{*}{ Juvenile (44) } & Positive & 42 & $19(43.2 \%)^{a \mathrm{~B}}$ & $23(52.3 \%)^{\mathrm{bA}}$ & 44 & $19(43.2 \%)^{\mathrm{aA}}$ & $25(56.8 \%)^{\mathrm{bA}}$ \\
\hline & Negative & 02 & 0 & $2(4.5 \%)$ & 0 & 0 & 0 \\
\hline \multirow[t]{2}{*}{ Sub-adult (23) } & Positive & 21 & $12(52.2 \%)^{\mathrm{aA}}$ & $9(39.2 \%)^{\mathrm{bB}}$ & 23 & $13(56.5 \%)^{\mathrm{aB}}$ & $10(43.5 \%)^{\mathrm{bB}}$ \\
\hline & Negative & 2 & $1(4.3 \%)$ & $1(4.3 \%)$ & 0 & 0 & 0 \\
\hline \multirow[t]{2}{*}{ Adults (15) } & Positive & 11 & $08(53.3 \%)^{\mathrm{aA}}$ & $3(20.0 \%)^{\mathrm{bc}}$ & 15 & $11(73.33 \%)^{\mathrm{ac}}$ & $4(26.66 \%)^{\mathrm{bC}}$ \\
\hline & Negative & 4 & $3(20.0 \%)$ & $1(6.7 \%)$ & 0 & 0 & 0 \\
\hline \multirow[t]{2}{*}{ Total (82) } & Positive & 74 & $39(47.6 \%)^{a}$ & $35(42.6 \%)^{a}$ & 82 & $43(52.4 \%)^{a}$ & $39(47.6 \%)^{a}$ \\
\hline & Negative & 8 & $4(4.9 \%)^{a}$ & $4(4.9 \%)^{a}$ & 0 & 0 & 0 \\
\hline
\end{tabular}

Different small superscripts refer to significant differences $(p<0.05)$ within same age group.

Different large superscripts refer to significant differences $(p<0.05)$ between age groups

Table-5: Concentrations of BUN and Creatinine in serum of captured rats.

\begin{tabular}{llcc}
\hline Age class (N) & Immunoglobulin G & BUN $(\mathbf{m g} / \mathbf{d L})$ & Creatinine $(\mathbf{m g} / \mathbf{d L})$ \\
\hline Juvenile (44) & Positive & $8.43 \pm 1.09^{\mathrm{a}}$ & $0.91 \pm 0.16^{\mathrm{a}}$ \\
& Negative & $11.37 \pm 2.32^{\mathrm{a}}$ & $1.12 \pm 0.27^{\mathrm{a}}$ \\
Sub-adult (23) & Positive & $21.56 \pm 2.87^{\mathrm{b}}$ & $2.89 \pm 0.31^{\mathrm{b}}$ \\
& Negative & $11.37 \pm 2.32^{\mathrm{a}}$ & $1.12 \pm 0.27^{\mathrm{a}}$ \\
Adults (15) & Positive & $36.25 \pm 5.13^{\mathrm{c}}$ & $8.26 \pm 1.69^{\mathrm{c}}$ \\
& Negative & $11.37 \pm 2.32^{\mathrm{a}}$ & $1.12 \pm 0.27^{\mathrm{a}}$ \\
\hline
\end{tabular}

Different superscripts refer to significant differences $(p<0.05)$ between age groups. BUN=Blood urea nitrogen

Table-6: Presence of leptospires in kidney and blood smear.

\begin{tabular}{|c|c|c|c|c|c|}
\hline \multirow[t]{2}{*}{ Age group } & \multirow[t]{2}{*}{ Immunoglobulin G } & \multirow[t]{2}{*}{$\mathbf{n}$} & \multirow[t]{2}{*}{ Blood smear } & \multicolumn{2}{|l|}{ Kidney } \\
\hline & & & & Hematoxylin and eosin & ws \\
\hline \multirow[t]{2}{*}{ Juvenile (44) } & Positive & 42 & - & - & - \\
\hline & Negative & 02 & - & - & - \\
\hline \multirow[t]{2}{*}{ Sub-adult (23) } & Positive & 21 & 13 & - & - \\
\hline & Negative & 02 & - & - & - \\
\hline \multirow[t]{2}{*}{ Adults (15) } & Positive & 11 & 1 & - & 8 \\
\hline & Negative & 04 & - & - & - \\
\hline \multirow[t]{2}{*}{ Total (82) } & Positive & 74 & 15 & - & \\
\hline & Negative & 8 & - & - & - \\
\hline
\end{tabular}




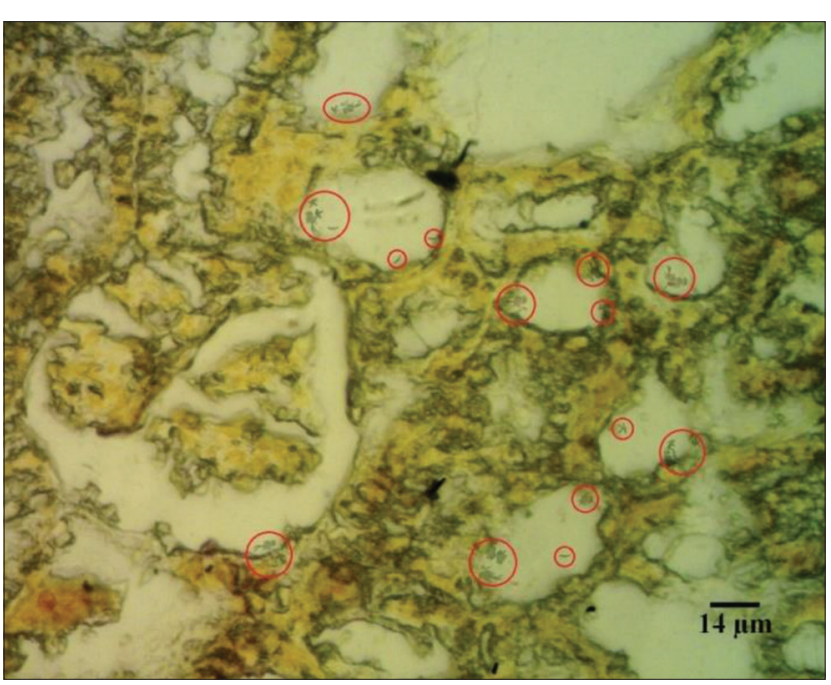

Figure-3: Microscopical findings of kidney of sub-adult immunoglobulin $G$ positive rats. Note the presence of Leptospira inside glomeruli (red circles) (WS stain).

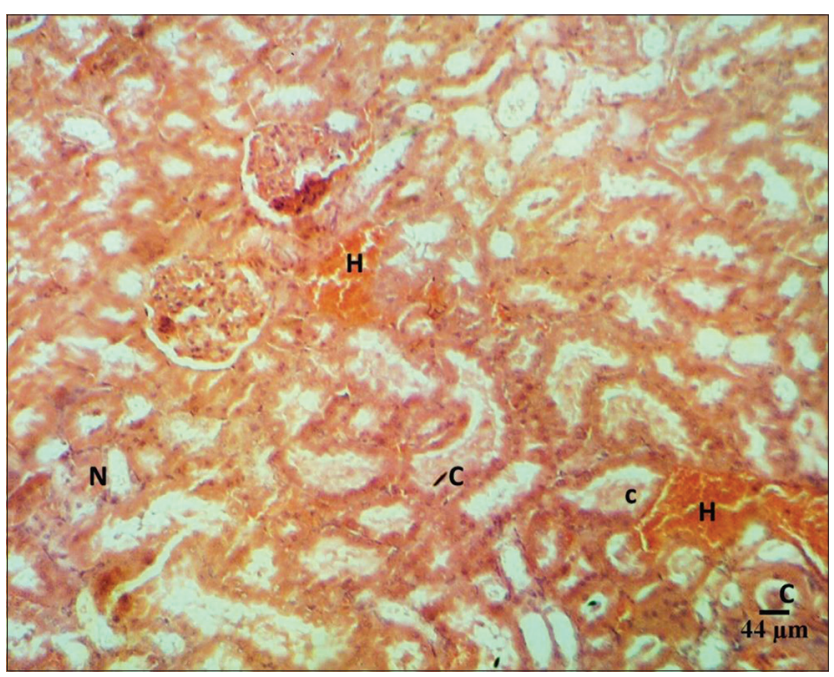

Figure-4: Microscopical findings of kidney cortex of adult immunoglobulin $\mathrm{G}$ positive rats. Note the Hemorrhage $(\mathrm{H})$ and congestion (C) (hematoxylin and eosin, stain).

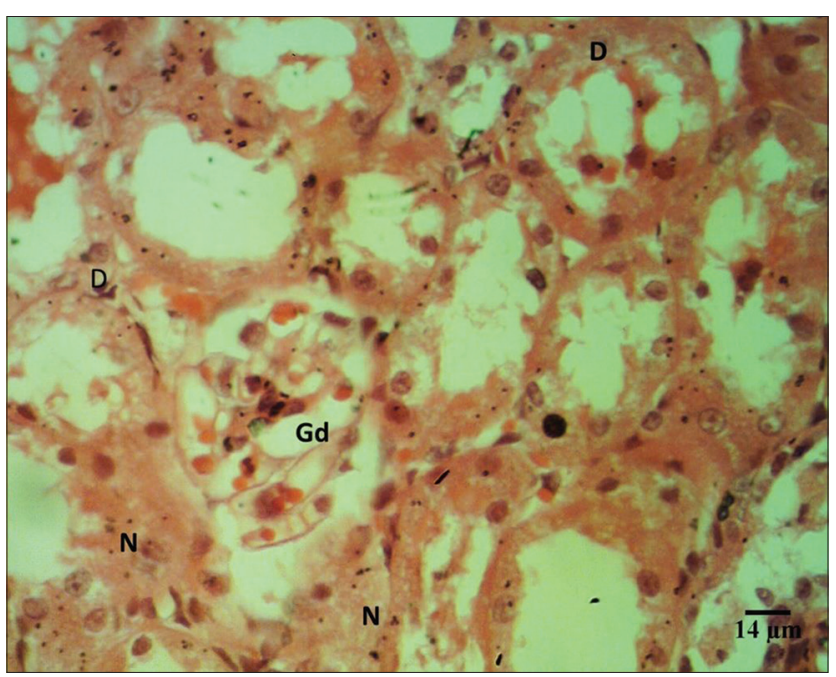

Figure-5: Microscopical findings of kidney -cortex of subadult immunoglobulin $\mathrm{G}$ positive rats. Note the tubular cells degeneration (D) and necrosis (N) with glomerular deterioration (hematoxylin and eosin, stain).

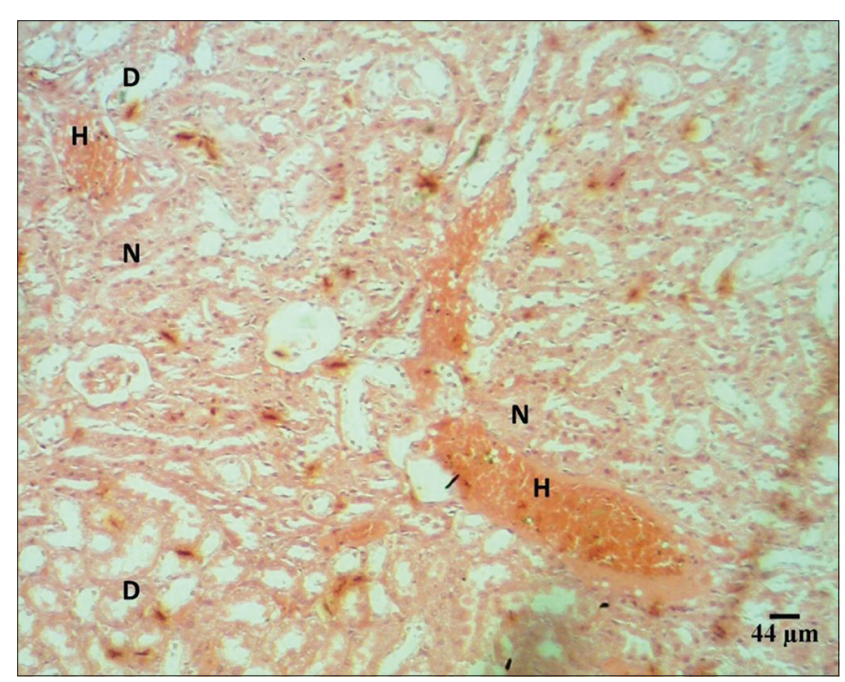

Figure-6: Microscopical findings of kidney cortex of subadult immunoglobulin $\mathrm{G}$ positive rats. Note the hemorrhage $(\mathrm{H})$, tubular cells degeneration (D), and necrosis (N) (hematoxylin and eosin, stain).

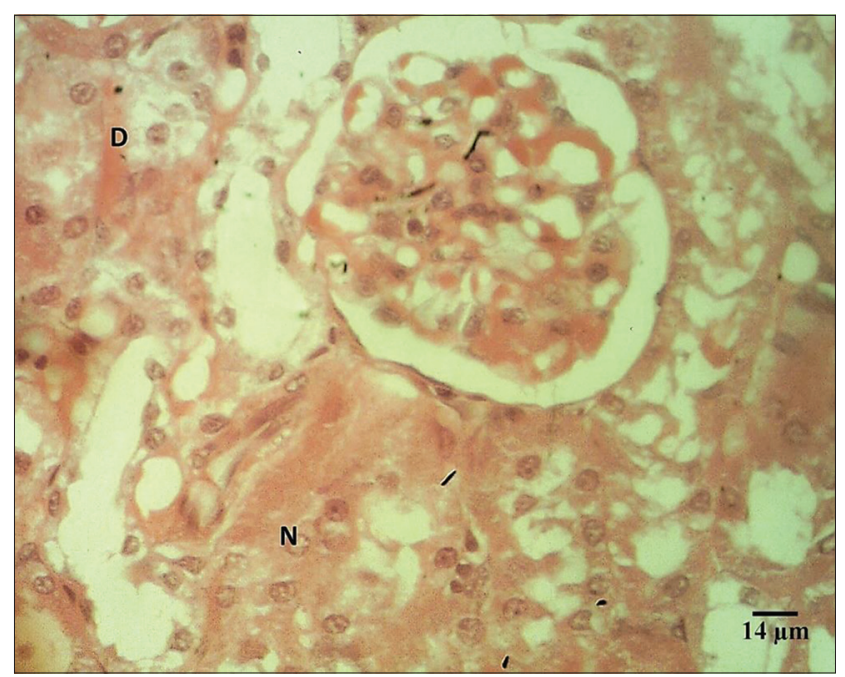

Figure-7: Microscopical findings of kidney cortex of subadult immunoglobulin $\mathrm{G}$ positive rats. Note the tubular cells degeneration (D) and necrosis (N) with normal glomerulus appearance (hematoxylin and eosin, stain).

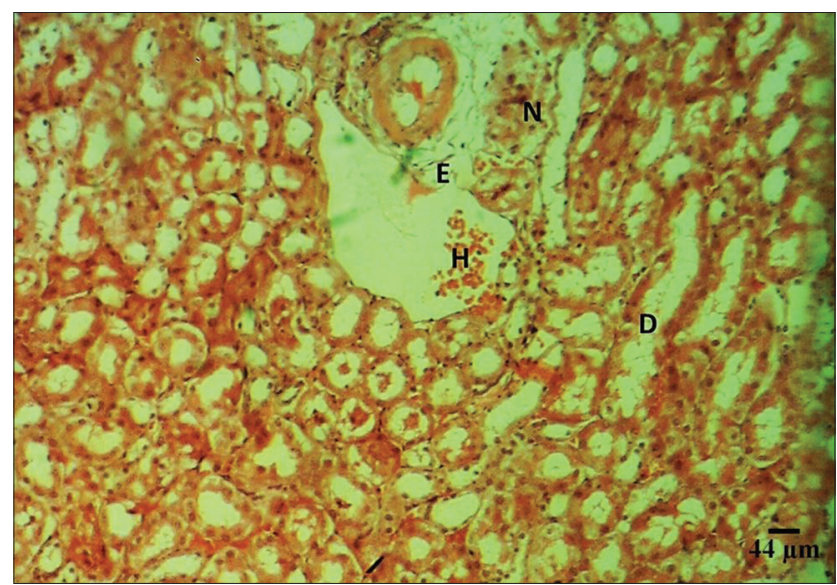

Figure-8: Microscopical findings of kidney medulla of subadult immunoglobulin $G$ positive rats. Note the tubular cells degeneration (D) and necrosis ( $N$ ) with cast formation (hematoxylin and eosin, stain). 


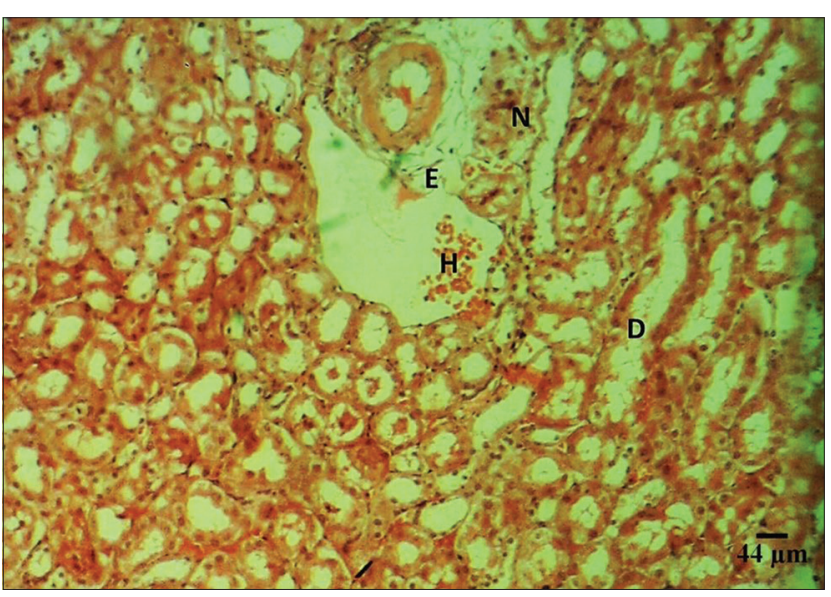

Figure-9: Microscopical findings of kidney of sub-adult immunoglobulin $G$ positive rats. Note the tubular cells degeneration (D) and necrosis (N) with periarterial edema $(E)$ and hemorrhage $(\mathrm{H})$ (hematoxylin and eosin, stain).

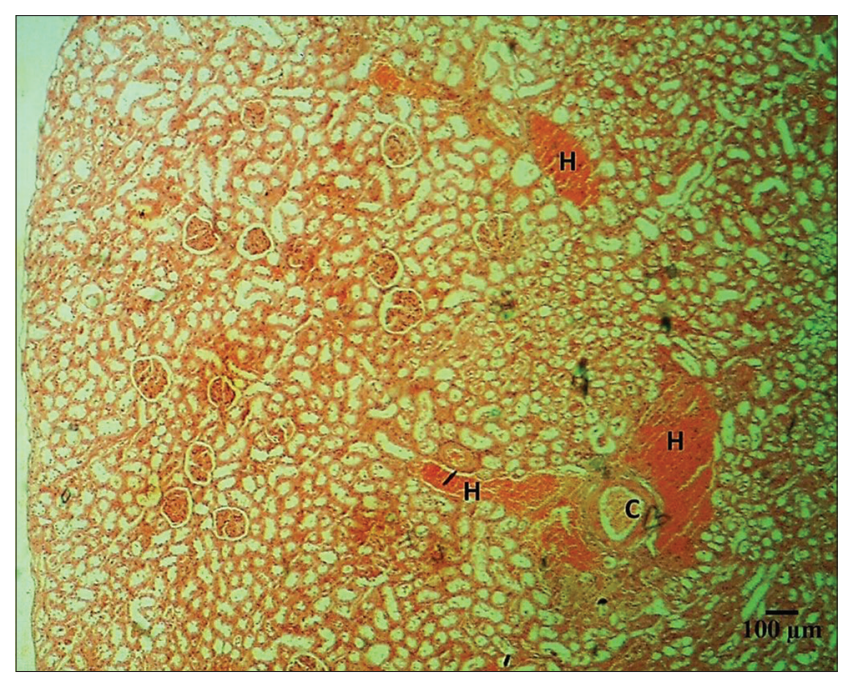

Figure-10: Microscopical findings of kidney of sub-adult immunoglobulin $\mathrm{G}$ positive rats. Note the focal hemorrhage $(\mathrm{H})$ with congestion of peritubular arteries (C) (hematoxylin and eosin, stain).

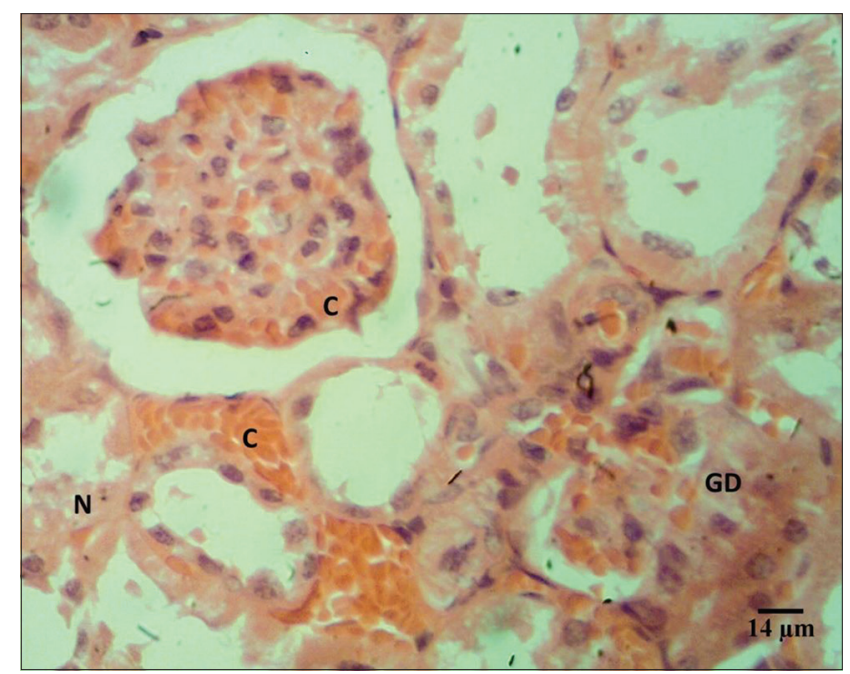

Figure-11: Microscopical findings of kidney-cortex of adult immunoglobulin $\mathrm{G}$ positive rats. Note the congestion of peritubular arteries and glomerular tuft congestion (C), tubular necrosis (N), and glomerular deterioration (hematoxylin and eosin, stain).

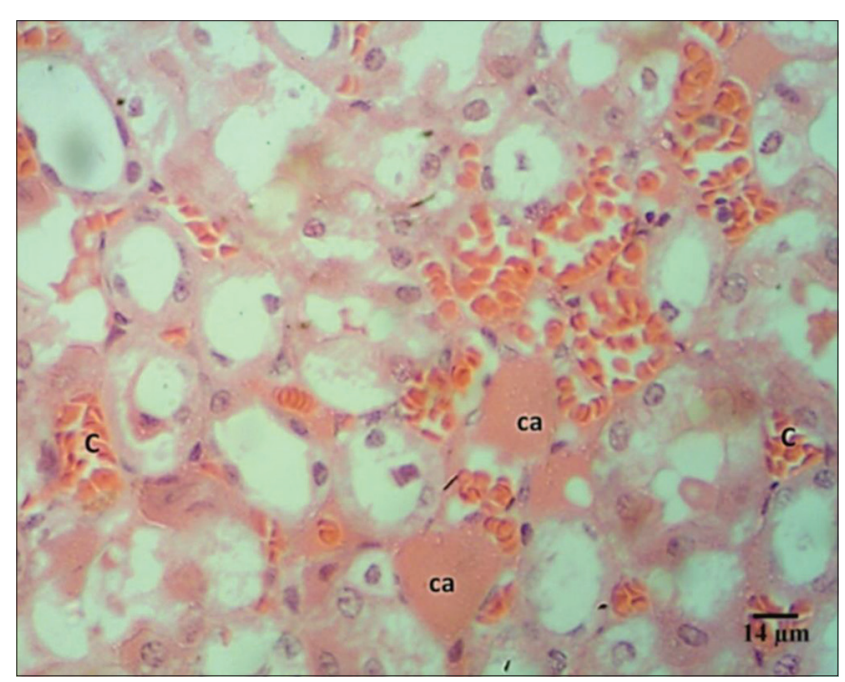

Figure-12: Microscopical findings of kidney of adult immunoglobulin $\mathrm{G}$ positive rats. Note the peritubular arterial congestion (C) and cast formation (ca) (hematoxylin and eosin, stain.)

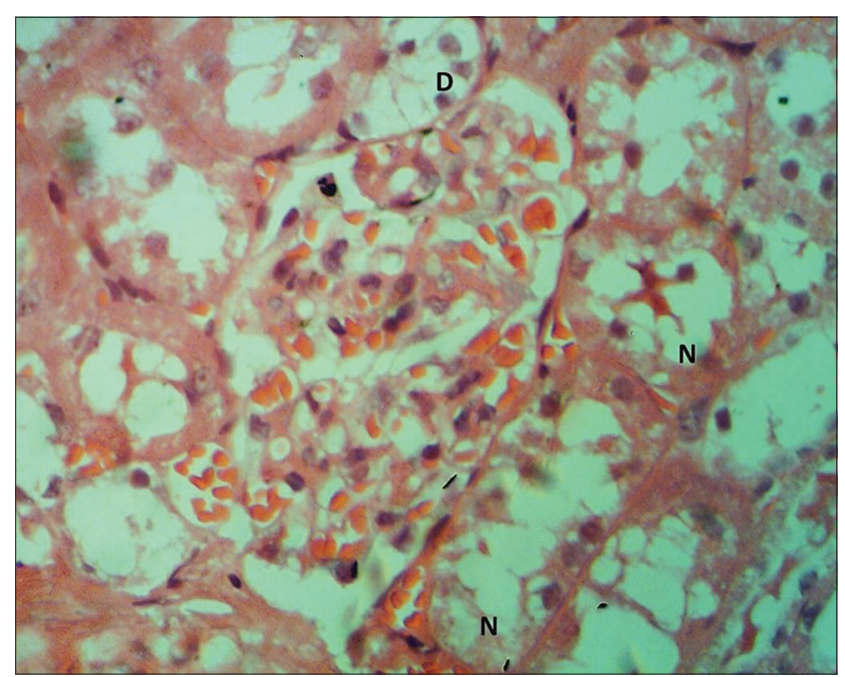

Figure-13: Microscopical findings of kidney-cortex of adult immunoglobulin $G$ positive rats. Note the tubular degeneration (D) and necrosis (N) with glomerular deterioration (hematoxylin and eosin, stain).

\section{Age of captured rats}

The use of age groups in this study conforms to the study by Choo et al. [34]. Despite that the number of males and females was equal (Table-1), considering the distribution of age groups, the juvenile group composed of significantly the largest number of rats. This might be explained by the fact that juvenile rats are not experts in collecting their food and look at the surroundings differently from the adult rats [34].

\section{ELISA}

Serum IgG was positive in all captured rats. This either refers to a current infection, chronic infection, or acquired IgG from the dam through milk $[35,36]$. Immunity following leptospiral infection is humorally mediated against lipopolysaccharides and antigenically restricted to related serovars [37]. De Oliveira et al. [35] have argued that Leptospira spp. was 
detected in the mammary glands and milk of naturally infected rats, which coincided with the presence of leptospires in the kidneys of all rats in this study, indicating chronic carriage. Records in Table- 2 indicate that $90.24 \%$ of the rats were IgG-positive in kidney homogenates. Although this rate is too high comparable to the findings of Heuser et al. [38], who detected Leptospira DNA in $14.3 \%$ of rats using polymerase chain reaction (PCR), this wide spectrum of variation may be attributed to the detection of the leptospire antigens in a later study, whereas this study was confined with the detection of antibodies.

Passive immunity, provided by the dam through the placenta and milk mainly containing $\operatorname{IgG}$ and IgA antibodies, offers protection against many bacterial and viral diseases [39]. The neonatal mammalian gut could absorb IgG for hours to days after birth. Failure of passive transfer of $\mathrm{IgG}$ can be fatal due to the lowered amount of maternal IgG in the blood to resist common diseases. Maternal IgG is correlated with the amount of suckled maternal antibody by the neonate referring to that higher titers persist for a longer time. The high concentration of IgG in the serum and kidney homogenates in juvenile rats is explained in this view (Table-4). Maternal antibodies usually persist for 3-6 months in domestic animals, only 4-7 days in chickens, and 6-12 months in humans [40,41]. Despite the prediction, that maternal immunoglobulins are passed through milk to the neonates, the seroprevalence of leptospires was higher than the detection of antigens. This was confirmed by a study performed on rats trapped in Barbados showing higher seropositivity prevalence rates of $34 \%$ in R. norvegicus and $30 \%$ in $R$. rattus, but lower identification rates using darkfield microscopy at $27 \%$ and $15 \%$, respectively [42]. These records conform to the findings in this study, although leptospire detection was not performed. Dreyfus et al. [43] have shown that the high seroprevalence (35\%) suggests an ongoing exposure. This suggestion potentiates the risk of a current infection among the rats studied.

The rate of Leptospira carriage in small mammals trapped in Eastern Croatia was high (29.9\%), which corresponds to the high incidence of human and domestic animal leptospirosis [44]. In another study, Hagan et al. [45] have revealed that Leptospira spp. was the most common pathogen in rats trapped in Brazil, which peaked at $90 \%$ as a presumptive infection based on serology. The prevalence of Leptospira spp. increased significantly in rats, which was comparable to that of Seoul virus and Bartonella spp. They have suggested differences in the transmission dynamics of these different pathogens, indicating the high prevalence of leptospiral carriage by rats and a high degree of risk to human health [45]. In humans, serological diagnosis using the microscopic agglutination test (MAT), IgM and IgG ELISA confirmed leptospirosis in children with acute febrile illnesses in Tanzania. The prevalence recorded was $13-41 \%$ in those who reside with rats with the ugliest danger risk reported; more than $95 \%$ of patients specifically reacted to agglutination using the MAT [46-48].

The high occurrence rates of antibodies in the serum and kidney homogenates (Table-4) could explain that rats are sharing the same contaminated environment leading to the preponderance of common asymptomatic infections in humans in endemic areas [49]. ELISA tests and PCR may play a key role in the early detection and treatment of human leptospirosis in developing countries [50]. Blanco et al. [51] have correctly identified infecting serogroups using MAT matching with the identification of isolates, which fit the epidemiological surveys. Lau et al. [50] have reported that IgM ELISA, real-time PCR, cPCR, and IgG ELISA had the greatest diagnostic accuracy. Due to the species of the rats used in this study, caring for the acute diagnosis of the disease was ignored. Alternatively, this study confirmed the usefulness of IgG ELISA for diagnosing either present or previous infection.

Comparing our serology findings with those of other studies on small ruminants, the seroprevalence in rats was $100 \%$ and $90.24 \%$ in the serum and kidney homogenates, respectively (Table-2). Sheep and goats residing in tropical St. Croix, US Virgin Islands showed seroprevalence rates of $32 \%$ and $26 \%$, respectively [52], which are comparable to $6.1 \%$ (sheep) and $2.1 \%$ (goat) in Italy [53]. The wide difference in seroprevalence may be attributed directly to the tools used for diagnosing [54]. The seroprevalence of leptospirosis in ovine livestock detected using the MAT in Tunisia was $25 \%$, whereas it reached $70 \%$ at the herd level. This evidence confirmed the chronic and active circulation of Leptospira in ovine, which may act as reservoirs or incidental hosts in which the productivity of small ruminants is significantly reduced [55-57]. The high endemicity (5.6\%) in Thailand, up to $25 \%$ in Colombia, was recorded for leptospirosis in rats trapped in urban and rural areas using the MAT $[58,59]$. These low prevalence rates detected using the MAT compared with our findings regarding ELISA IgG2 (Table-2) evoke the necessity of using more than one tool in diagnosing leptospirosis. The sensitivity of ELISA is $72 \%$ (comparable to that of the MAT) during acute illness, which is lowered to $<25 \%$ during the critical $1^{\text {st }}$ week of illness when antibiotic therapy is most effective [60-62]. The high seroprevalence rate reported in this study predicts that rats play a key role in dispersing Leptospira in its surroundings.

\section{Young animals affected more than other}

The highest occurrence of leptospiral IgG was recorded in the juvenile group (Table-3). Whether serum IgG in neonates acquired from the dam or from a valid infection, many researchers refer to younger age to be the most susceptible. This was confirmed in rats [45], lambs [56], dogs [63], piglets [64], and children $[47,48]$. In addition to the milk route, leptospirosis 
could be transmitted to neonates through semen [65], causing $\operatorname{IgG}$ induction, although some of these antigens might be neutralized by maternal IgG [64]. The former facts potentiate our findings regarding the elevated IgG concentration in juvenile rats.

In humans, all ages are susceptible, and the highest incidence of leptospirosis occurred in individuals aged above 55 and 65 years in both genders [47]. Ciceroni et al. [53] have found that all age groups (1564 years) were prone to infection, but infection was more common in the working-age population [53]. Similar findings were reported by Holk et al. [66] who recorded $93 \%$ of the patients aged 18-64 years. Infection was reported in the lower age individuals (1534 years) who reside close to an open sewer $[47,67]$ or individuals aged between 19 and 29 years performing piggery-farming activities [68]. The mortality rate is higher in the elderly than that in young adults who are more prone to subclinical leptospirosis [69].

\section{Gender susceptibility}

The presence of IgG in the serum or kidney homogenates varies between genders (Table-4). No significant difference in the total $\operatorname{IgG}$ value in kidney homogenates and the serum between males $(47.6 \%$ and $52.4 \%$, respectively) and females $(42.6 \%$ and $47.6 \%$, respectively). This might be explained by the fact that both genders are exposed to the same pathogenic serotype and same environmental conditions. This coincided with the results of a study that has reported that gender-related differences were not associated with exposure risk, infecting serovars, or health-seeking behavior [70]. Many sero-epidemiologic studies have reported that males are 3 times more likely to be infected with leptospirosis with a higher severity than females, whereas death from leptospirosis was nearly twice as common among females [70,71]. Thus, leptospirosis predominance in males reflects gender variations in the incidence of severity of the disease, rather than difference in infection rates.

As for many other diseases, including tuberculosis, listeriosis, and amebiasis [72-75], gender may influence the severity and outcome of clinical leptospirosis [76]. Males have increased susceptibility to not only leptospirosis but also many other infections and the development of diseases [72-74]. This was attributed in part to the effect of estrogen [73]. Conventionally, the altitude in male incidence is explained by higher exposure to risk factors associated with occupations typically confined to males, such as butchering, livestock farming, rice farming, and fishing. Alternatively, a major cause of leptospirosis emerged as travel-related in developed countries [77]. In the Netherlands, Goris et al. [78] have reported that $91.1 \%$ of male patients are infected with leptospirosis compared with $8.9 \%$ for female patients. A higher incidence rate of leptospirosis $($ Male/Females $=5.4)$ in males than that in females was recorded in the Pacific [78]. In addition, males showed severe leptospirosis infection with
$6.9 \%$ died compared with $2.7 \%$ in females [77]. The incidence of leptospirosis cases was $74 \%-90 \%$ among men $[66,79]$, and the mortality rate among males was higher than that among females $[53,67]$. Whether it only reflects higher exposure of male gender due to their responsibilities in agricultural and farming activities or sex-specific susceptibility factors is not yet confirmed.

\section{Kidney function tests}

Renal function is clinically estimated using the glomerular filtration rate. Levels of BUN and serum creatinine are considered important indicators of kidney health [80]. Serum creatinine is the most commonly used tool for the indirect detection of marked damage to functioning nephrons and indicates late-stage renal dysfunction [81]. The removal of creatinine from the blood is chiefly performed by glomeruli and proximal tubules in the kidneys. Deficient renal filtration of creatinine raises its blood levels. Therefore, serum and urine creatinine levels may be used as indicators of creatinine clearance. Myositis, a common clinical feature in leptospirosis usually fading by the $2^{\text {nd }}$ week, is linked to high creatine phosphokinase (CPK) levels [71]. The increased creatinine levels in both the sub-adult and adult groups in this study were confirmed by many studies linking leptospirosis to extremely high CPK levels [80-82]. CPK determination is a simple test that may provide diagnostic information in a jaundiced patient, particularly when characteristic manifestations of leptospirosis are absent, suggesting a diagnosis of leptospirosis [82]. Moreover, Knopfler et al. [81] have supported our results. They have argued that creatinine and BUN are markedly elevated in dogs, equine, and Wistar rats with acute leptospirosis $[82,83]$. In humans, renal, and pulmonary involvement is commonly present in acute leptospirosis. In renal involvement, creatinine exceeding $3.0 \mathrm{mg} / \mathrm{dL}$ is a strong predictor of death [70]. Our study showed that creatinine reached this value in the sub-adult group and approximately 3 times in the adult group (Table-5). This finding revealed the degree of damage inside the kidneys and might explain the shorter life span of the wild rats than the laboratory rats due to renal failure. Nonetheless, the collaboration of a marked increase in creatinine level with damage to renal tubules may present a reliable understanding of renal failure that predicts a lethal outcome in severe leptospirosis [70]. BUN concentration is a less specific marker of kidney function than serum creatinine [83]. Our findings (Table-5) revealed 2-3 times increment in BUN in the sub-adult and adult IgG-positive groups comparable to those in seronegative rats. Studies have shown that if urea and creatinine are increased, a minimum of $75 \%$ of the nephrons must have lost their function [83].

\section{Histopathology}

It was suggested that in acute leptospirosis, the pathogenesis of the pathological features is related 
to the presence of organisms in the tissues [84]. This was evident in our observations. The presence of leptospires in the blood smears (Figure-2) indicates the acute phase of leptospirosis in the sub-adult group (Table-6 and Figure-3). The rest of the sub-adult IgGpositive rats were suspected to have a continuation of maternal immunity or a valid infection. This cannot be confirmed unless a PCR is performed $[54,84]$. In acute leptospirosis, the main pathogenesis was probably due to the direct toxic damage of leptospires [71]. Systemic lesions in leptospirosis are caused by direct damage to the parenchymal cellular membranes, causing functional disorder, and necrosis. This deterioration may predispose patients to hemophagocytosis and disseminated intravascular coagulation, which are dominant in Gram-negative bacterial diseases but rarely present in human leptospirosis $[82,85]$.

Using H\&E staining, the kidneys exhibited histopathological changes manifested by interstitial nephritis that predominantly consisted of lymphocytes (Figures-4-13). Tubulointerstitial nephritis is a main renal manifestation caused by pathogenic Leptospira that mostly accumulates in the proximal tubules, by a toxic component in the outer membrane (e.g., 32-kD lipoprotein, which is absent in the nonpathogenic Leptospira), cause macrophage accumulation and disrupted the basolateral location of $\mathrm{Na}-\mathrm{K}-\mathrm{ATPase}$ in pronephric ducts resulted in substantial impairment in the proximal tubular defect without affecting distal nephrons [86]. Mortality due to acute renal failure is approximately $15-20 \%$ in association with the presence of higher levels of creatinine [87].

Detecting the presence of leptospires in urine or in blood or tissues is difficult [88]. Many authors have detected leptospires in various body fluids of cattle, sheep, and goat using dark-field microscopy and confirmed by PCR, without bacterial isolation [62]. Our tools for detecting leptospires in the blood smears and kidneys were using silver impregnation (WS) and H\&E stains. The outcome of these staining methods to identify the bacteria in the same rat varied, but only one rat from the adult group revealed a positive blood smear coincided with the presence of leptospires in the kidney (Table-6).

The occurrence of antibodies against many serovars without leptospiral isolation cannot establish a diagnosis of the disease [88], even during the early acute phase of the disease, where IgM ELISA can give a presumptive diagnosis of leptospirosis [89]. Unlike ELISA, PCR can accurately confirm the disease. Rojas et al. [90] have confirmed leptospires that colonize the renal tubules in the urine of $7.05 \%$ of chronically infected dogs using PCR. AgudeloFlórez et al. [59] have reported that even in WS staining-positive kidneys, negative bacterial isolation was obtained from $\mathrm{H} \& \mathrm{E}$ staining and culture or even from PCR-LipL32 on $R$. norvegicus naturally infected from an urban area in Colombia. Several factors may prevent the growth of Leptospira in the specimens.
For example, the acidity of urine and the presence of specific antibodies and other bacterial contamination may directly interfere with the growth of leptospires and their isolation [91].

Renal involvement is common in leptospirosis, characterized by tubulointerstitial nephritis (Figure-6), resulting in tubular dysfunction. Yang [91] has reported that leptospiral outer membrane proteins (OMPs) may elicit tubular injury and inflammation through the Toll-like receptor-dependent pathway followed by the activation of nuclear transcription factor-kappa $B$ and mitogen-activated protein kinases motivated by differential induction of chemokines and cytokines relevant to tubular inflammation. Leptospiral OMP may also induce the activation of the transforming growth factor-beta/Smad-associated fibrosis pathway leading to the accumulation of extracellular matrix [91]. Fanton d'Andon et al. [92] have argued that renal colonization of Leptospira could induce mild renal fibrosis through TLR- and NLR-independent pathways, and the activation of iNOS plays a role in the initiation of renal fibrosis. Fibrosis results in structural and functional renal alterations characterized by excessive accumulation of scarring tissues, which may lead to organ dysfunction [6]. In addition, Lau et al. [50] have demonstrated leptospires in the renal tubules of seropositive cows (12.5\%) using WS staining, which conforms to the studies by Yener and Keles [93] and Saglam et al. [94]. Interstitial nephritis, tubular atrophy, and glomerular lesions of minimal intensity described in our results conform to the findings of many authors $[50,95]$.

\section{Conclusion}

IgG-positive carrier rats refer to previously exposed or infected rats. The risk of transmitting the disease to humans and animals through urine is highly predicted and possible mitigation of zoonotic transmission.

\section{Authors' Contributions}

AJK contributed to the design of the study, writing, analyzed data, and revision. ZMA performed the experiment, analyzed data, and wrote the draft. Both authors read and approved the final manuscript.

\section{Acknowledgments}

The authors expressed their gratitude to the College of Veterinary Medicine, University of Baghdad, for financing the project (Grant no. 2705/2016) and providing all facilities.

\section{Competing Interests}

The authors declare that they have no competing interests.

\section{Publisher's Note}

Veterinary World (Publisher of International Journal of One Health) remains neutral with regard 
to jurisdictional claims in published institutional affiliation.

\section{References}

1. Gaudie, C.M., Featherstone, C.A., Phillips, W.S., McNaught, R., Rhodes, P.M., Errington, J., Fearnley, C., Fenner, J.S. and Pritchard, G.C. (2008) Human Leptospira interrogans serogroup icterohaemorrhagiae infection (Weil's disease) acquired from pet rats. Vet. Rec., 163(20): 599-601.

2. Resnhaleksmana, E., Artama, W.T., Wijayanti, M.A. and Fihiruddin, F. (2020) Molecular genotypes analysis of Cryptosporidium and Hymenolepis in rats on Lombok Island, Indonesia. Int. J. One Health, 6(2): 123-127.

3. Goarant, C. (2016) Leptospirosis: Risk factors and management challenges in developing countries. Res. Rep. Trop. Med., 7(Sept.): 49-62.

4. Soo, Z.M.P., Khan, N.A. and Siddiqui, R. (2020) Leptospirosis: Increasing importance in developing countries. Acta Trop., 201(Jan.): 105183.

5. Wangdi, K., Kasturiaratchi, K., Vaz Nery, S., Lau, C.L., Gray, D.J. and Clements, A.C.A. (2019) Diversity of infectious aetiologies of acute undifferentiated febrile illnesses in south and Southeast Asia: A systematic review. BMC Infect. Dis., 19(1): 577-593.

6. Picardeau, M. (2017) Virulence of the zoonotic agent of leptospirosis: Still terra incognita? Nat. Rev. Microbiol., 15(5): 297-307.

7. Guernier, V., Goarant, C., Benschop, J. and Lau, C.L. (2018) A systematic review of human and animal leptospirosis in the Pacific Islands reveals pathogen and reservoir diversity. PLoS Negl. Trop. Dis., 12(5): e0006503.

8. Tanaka, K., Tanabe, K., Nishii, N., Takiue, K., Sugiyama, H. and Wada, J. (2017) Sustained tubulointerstitial inflammation in kidney with severe leptospirosis. Intern. Med., 56(10): 1179-1184

9. Wysocki, J., Liu, Y. and Shores, N. (2014) Leptospirosis with acute liver injury. Proc. Bayl. Univ. Med. Cent., 27(3): 257-258.

10. Nordholm, A.C., Omland, L.H. and Villumsen, S. (2019) Leptospirosis meningitis transmission from a pet mouse: A case report. J. Med. Case Rep., 13(1): 362.

11. Maier, A., Kaeser, R. and Thimme, R. (2019) Acute pancreatitis and vasoplegic shock associated with leptospirosis-a case report and review of the literature. Infect. Dis., 19(1): 395.

12. George, P. and Fernandes, D. (2013) Erythema nodosum-an unusual presenting feature of leptospirosis. J. Med., 14(1): 99.

13. Sharp, T.M., García, B.R., Pérez-Padilla, J., Galloway, R.L., Guerra, M., Ryff, K.R., Haberling, D., Ramakrishnan, S., Shadomy, S., Blau, D., Tomashek, K.M. and Bower, W.A. (2016) Early indicators of fatal leptospirosis during the 2010 epidemic in Puerto Rico. PLoS Negl. Trop. Dis., 10(2): e0004482.

14. Abdollahpour, G.R., Shafighi, S.T. and Sattari Tabrizi, S. (2009) Serodiagnosis of leptospirosis in cattle in north of Iran, Gilan. Int. J. Vet. Res., 31(1): 7-10.

15. Gumussoy, K.S., Ozdemir, V., Aydin, F., Aslan, O., Atabek, E., Ica, T., Dogan, O., Duman, Z. and Ozturk, A. (2009) Seroprevalence of bovine leptospirosis in Kayseri, Turkey detection of leptospirosis by polymerase chain reaction. J. Anim. Vet. Adv., 8(6): 1222-1229.

16. Al-Mawla, A.H.T. (2007) Isolate and Diagnose the Bacteria Leptospirosis from Various Medical Conditions in the City of Mosul. MSc Thesis. Faculty of Science, University of Mosul, Iraq.

17. Abu-Al-Maaly, N.M.H. (2008) Diagnosis of Leptospirosis Using PCR Technique. MSc Thesis. College of Veterinary Medicine, Baghdad University, Iraq.

18. Al-Sungari, S.H.A. (2009) Compared to Diagnostic Methods for Phenotypic Bremiat from Various Sources and Confirm Diagnosis Technology, Polymerase Chain
Reaction. MSc Thesis. Faculty of Science, University of Mosul, Iraq.

19. Al-Badrawi, T.Y.G., Habasha, F.G. and Sultan, S.H. (2010) Sociological study of leptospirosis in cattle, sheep and goats in Baghdad Province. Al Anbar J. Vet. Sci., 3(1): 78-82.

20. Ali, J.F., Obed, A.I. and Hussan, A.S. (2010) Serological diagnosis of leptospirosis in the city of Nasiriyah. Tikrit $J$. Pure Sci., 15(1): 92-98.

21. Ajaj, E.A. and AL-Farwachi, M.I. (2013) Detection of bovine leptospirosis using different conventional laboratory tests in Nineveh province, Iraq. J. Anim. Health Prod., 1(3): 32-35.

22. Asgari, Q., Motazedian, M.H., Mehrabani, D., Oryan, A., Hatam, G.R., Owji, S.M. and Paykari, H. (2007) Zoonotic cutaneous leishmaniasis in Shiraz, Southern Iran: A molecular, isoenzyme and morphologic approach. J. Res. Med. Sci., 12(1): 7-15.

23. Struck, M.B., Andrutis, K.A., Ramirez, H.E. and Battles, A.H. (2011) Effect of a short-term fast on ketamine-xylazine anesthesia in rats. J. Am. Assoc. Lab. Anim. Sci., 50(3): 344-348.

24. Schlafer, D.H. and Foster, R.A. (2016) Female genital system. In: Jubb, Kennedy and Palmer's Pathology of Domestic Animals. Vol. 3. Elsevier, Amsterdam, Netherlands. p358-464.

25. Islam, N.N., Akter, M., Farzana, Z. and Bin Kader, A. (2014) Detection of Staphylococcus aureus in frozen chicken rinse through bacteriological and $N u c$ gene-specific PCR methods and their drug resistance patterns in Southern Chittagong, Bangladesh. Res. J. Microb., 9(5): 251-264.

26. Luna, L. (1968) Manual of Histologic Staining Methods of the Armed Forces Institute of Pathology. McGraw-Hill, New York. p114-115.

27. Kiernan, J.A. (2002) Silver staining for spirochetes in tissues: Rationale, difficulties, and troubleshooting. Lab. Med., 33(9): 705-708.

28. Gounden, V., Bhatt, H. and Jialal, I. (2020) Renal Function Tests. Stat Pearls Publishing. Available from: https:// www.ncbi.nlm.nih.gov/books/NBK507821. Retrieved on 22-10-2020

29. Karim, A.J. (2010) Pathological Responses to Intratracheally Instilled Polycyclic Aromatic Hydro Carbons and Effect of Curcumin Towards These Responses in Sprague Dawley Rats. Ph.D. Thesis. University Putra Malaysia, Malaysia.

30. Karim, A.J. and Al-Salihi, K.A. (2014) Diagnostic study on accidental Hymenolepis diminuta Infection in laboratory rats in Iraq. MRVSA, 3(3): 33-40.

31. Sahar, K.K., Nagham, M.A., Abdulkarim J.K. and Jenan M.K. (2015) Isolation of methicillin-resistant Staphylococcus aureus (MRSA) from Rattus rattus from Adhamiyah district in Baghdad governorate. MRVSA, 4(3): 9-23.

32. Ayyal, N.M., Abbas, Z.A., Karim, A.J., Abbas, Z.M., Al-Salihi, K.A., Khalaf, J.M., Mahmood, D.D., Mohammed, E.A., Jumaa, R.S. and Abdul-Majeed, D.I. (2019) Bacterial isolation from internal organs of rats (Rattus rattus) captured in Baghdad city of Iraq. Vet. World, 12(1): 119-125.

33. Clement, J., LeDuc, J.W., Lloyd, G., Reynes, J.M., McElhinney, L., Van Ranst, M. and Lee, H.W. (2019) Wild rats, laboratory rats, pet rats: Global Seoul hantavirus disease revisited. Viruses, 11(7): 652.

34. Choo, E., Wong, L., Chau, P., Bushnell, J. and Dando, R. (2020) Offspring of obese mice display enhanced intake and sensitivity for palatable stimuli, with altered expression of taste signaling elements. Sci. Rep., 10(1): 12776.

35. De Oliveira, D., Figueira, C.P. and Zhan, L. (2016) Leptospira in breast tissue and milk of urban Norway rats (Rattus norvegicus). Epidemiol. Infect., 144(11): 2420-2429.

36. Boey, K., Shiokawa, K. and Rajeev, S. (2019) Leptospira infection in rats: A literature review of global prevalence 
and distribution. PLoS Negl. Trop. Dis., 13(8): e0007499.

37. Bashiru, G. and Bahaman, A.R. (2018) Advances and challenges in leptospiral vaccine development. Indian J. Med. Res., 147(1): 15-22.

38. Heuser, E., Fischera, S., Rylla, R., Mayer-Schollb, A., Hoffmannc, D., Spahrb, C., Imholtd, C., Alfaa, DM., Fröhliche, A., Lüschowf, D., Johneb, R., Ehlersg, B., Essbauerh, S., Nöcklerb, K. and Ulrich, R.G. (2016) Survey for zoonotic pathogens in Norway rat populations from Europe. Pest. Manag. Sci., 73(2): 341-348.

39. Zheng, W., Zhao, W. and Wu, M. (2020) Microbiotatargeted maternal antibodies protect neonates from enteric infection. Nature, 577(7791): 543-548.

40. Gharaibeh, S. and Mahmoud, K. (2013) Decay of maternal antibodies in broiler chickens. Poult. Sci., 92(9): 2333-2336.

41. Amanna, I.J., Slifka, M.K. and Crotty, S. (2006) Immunity and immunological memory following smallpox vaccination. Immunol. Rev., 211(June): 320-337.

42. Taylor, K.D.., Turner, L.H. and Everard, J.D. (1991) Leptospires in Rattus spp. On Barbados. J. Trop. Med. Hyg., 94(2): 102-103.

43. Dreyfus, A., Dyal, J.W., Pearson, R., Kankya, C., Kajura, C., Alinaitwe, L., Kakooza, S., Pelican, K.M., Dominic, A., Travis, D.A., Mahero, M., Boulware, D.R. and Mugisha, L. (2016) Leptospira seroprevalence and risk factors in health centre patients in Hoima district, Western Uganda. PLoS Negl. Trop. Dis., 10(8): e0004858.

44. Majetic, Z.S., Galloway, R., Sabljic, E.R., Milas, Z., Perko, V.M. and Habus, J. (2014) Epizootiological survey of small mammals as Leptospira spp. reservoirs in Eastern Croatia. Acta Trop., 131(Mar.): 111-116.

45. Hagan, J.E., Moraga, P., Costa, F., Capian, N. and Ribeiro, G.S. (2016) Spatiotemporal determinants of urban leptospirosis transmission: Four-year prospective cohort study of slum residents in Brazil. PLoS Negl. Trop. Dis., 10(1): e0004275.

46. Silva, H.R., Tavares-Neto, J., Bina, J.C. and Meyer, R. (2003) Leptospiral infection and subclinical presentation among children in Salvador, Bahia. Rev. Soc. Bras. Med. Trop., 36(2): 227-233.

47. Maciel, E.A.P., de Carvalho, A.L.F., Nascimento, S.F., de Matos, R.B., Gouveia, E.L., Reis, M.G. and Ko, A.I. (2008) Household transmission of Leptospira infection in Urban slum communities. PLoS Negl. Trop. Dis., 2(1): e154.

48. Chipwaza, B., Mhamphi, G.G., Ngatunga, S.D., Selemani, M., Amuri, M. and Mugasa, J.P. (2015) Prevalence of bacterial febrile illnesses in children in Kilosa District, Tanzania. PLoS Negl. Trop. Dis., 9(5): e0003750.

49. Ashford, D.A., Kaiser, R.M., Spiegel, R.A., Perkins, B.A., Weyant, R.S., Bragg, S.L., Plikaytis, B., Jarquin, C., De Lose Reyes, J.O. and Amador, J.J. (2000) Asymptomatic infection and risk factors for leptospirosis in Nicaragua. Am. J. Trop. Med. Hyg., 63(5-6): 249-254.

50. Lau, C.L., Watson, C.H., Lowry, J.H., David, M.C., Craig, S.B., Wynwood, S.J., Kama, M. and Nilles, E.J. (2016) Human leptospirosis infection in Fiji: An eco-epidemiological approach to identifying risk factors and environmental drivers for transmission. PLoS Negl. Trop. Dis., 10(1): e0004405.

51. Blanco, R.M., dos Santos, L.F., Galloway, R.L. and Romero, E.C. (2016) Is the microagglutination test (MAT) good for predicting the infecting serogroup for leptospirosis in Brazil? Comparative immunology. Microbiol. Infect. Dis., 44(Feb.): 34-36.

52. Ahl, A.S., Miller, D.A. and Bartlett, P.C. (1992) Leptospira serology in small ruminants on St. Croix, U.S. Virgin Islands. Ann. N. Y. Acad. Sci., 653(June): 168-171.

53. Ciceroni, L., Lombardo, D., Pinto, A., Ciarrocchi, S. and Simeoni, J. (2000) Prevalence of antibodies to Leptospira serovars in sheep and goats in Alto Adige-South Tyrol. $J$. Vet. Med. B, 47(3): 217-223.

54. Podgoršek, D., Ružić-Sabljić, E., Logar, M., Pavlović, A.,
Remec, T., Baklan, Z., Pal, E. and Cerar, T. (2020) Evaluation of real-time PCR targeting the lipL32 gene for diagnosis of Leptospira infection. BMC Microbiol., 20(1): 59.

55. Picardeau, M. (2013) Diagnosis and epidemiology of leptospirosis. Med. Mal. Infect., 43(1): 1-9.

56. Martins, G. and Lilenbaum, W. (2014) Leptospirosis in sheep and goats under tropical conditions. Trop. Anim. Health Prod., 46(1): 11-17.

57. Cortizo, P., Loureiro, A.P., Martins, G., do Rodrigues, P.R., Faria, B.P., Lilenbaum, W. and Deminicis, B.B. (2015) Risk factors to incidental leptospirosis and its role on the reproduction of ewes and goats of Espírito Santo state, Brazil. Trop. Anim. Health Prod., 47(1): 231-235.

58. Kositanont, U., Naigowit, P., Imvithaya, A., Singchai, C. and Puthavathana, P. (2003) Prevalence of antibodies to Leptospira serovars in rodents and shrews trapped in low and high endemic areas in Thailand. J. Med. Assoc. Thai., 86(2): 136-142.

59. Agudelo-Flórez, P., Murillo, V.E., Londoño, A.F. and Rodas, J.D. (2013) Histopathological kidney alterations in rats naturally infected with Leptospira. Biomedica, 33(1): 82-88.

60. Effler, P.V., Bogard, A.K., Domen, H.Y., Katz, A.R., Higa, H.Y. and Sasaki, D.M. (2002) Evaluation of eight rapid screening tests for acute leptospirosis in Hawaii. $J$. Clin. Microbiol., 40(4): 1464-1469.

61. Lunn, K.F. (2020) Leptospirosis. In: Clinical Small Animal Internal Medicine. John Wiley \& Sons, Inc., United States. p945-949.

62. Lilenbaum, W., Varges, R., Ristow, P., Cortez, A., Souza, S.O., Richtzenhain, L.J. and Vasconcellos, S.A. (2009) Identification of Leptospira spp. Carriers among seroreactive goats and sheep by polymerase chain reaction. Res. Vet. Sci., 87(1): 16-19.

63. Lizer, J., Velineni, S., Weber, A., Krecic, M. and Meeus, P. (2018) Evaluation of 3 serological tests for early detection of Leptospira-specific antibodies in experimentally infected dogs. J. Vet. Intern. Med., 32(1): 201-207.

64. Niewiesk, S. (2014) Maternal antibodies: clinical significance, mechanism of interference with immune responses, and possible vaccination strategies. Front. Immunol., 5: 446-460.

65. Director, A., Penna, B., Hamond, C., Loureiro, A.P., Martins, G., Medeiros, M.A. and Lilenbaum, W. (2014) Isolation of Leptospira interrogans hardjoprajitno from vaginal fluid of a clinically healthy ewe suggests potential for venereal transmission. J. Med. Microbiol., 63(9): 1234-1236.

66. Holk, K., Nielsen, S.V. and Rønne, T. (2000) Human leptospirosis in Denmark 1970-1996: An epidemiological and clinical study. Scand. J. Infect. Dis., 32(5): 533-538.

67. Felzemburgh, R.D.M., Ribeiro, G.S., Costa, F., Reis, R.B., Hagan, J.E., Melendez, A.X., Fraga, D., Santana, F.S., Mohr, S., dos Santos, B.L., Silva, A.Q., Santos, A.C., Ravines, R.R., Tassinari, W.S., Carvalho, M.S., Reis, M.G. and Ko, A.I. (2014) Prospective study of leptospirosis transmission in an urban slum community: Role of poor environment in repeated exposures to the Leptospira agent. PLoS Negl. Trop. Dis., 8(5): e2927.

68. Massenet, D., Yvon, J.F., Couteaux, C. and Goarant, C. (2015) An unprecedented high incidence of leptospirosis in Futuna, South Pacific, 2004-2014, evidenced by retrospective analysis of surveillance data. PLoS One, 10(11): $\mathrm{e} 0142063$.

69. Isselbacher, K.J., Braunwald, E. and Wilson, J.D. (1993) Harrison's Principles of Internal Medicine. $14^{\text {th }}$ ed. McGraw-Hill, St. Louis. p1036-1038.

70. Anne, S.S., Pedro, J.V., Daniel, A.A., Jose, O.M.A., Marcia, B., Bronislawa, C., Antonio, S. and Joseph, M.V. (2008) Predictors of lethality in severe leptospirosis in Urban Brazil. Am. J. Trop. Med. Hyg., 79(6): 911-914.

71. Haake, D.A. and Levett, P.N. (2015) Leptospirosis in humans. Curr. Top. Microbiol. Immunol., 387: 65-97. 
72. Blessmann, J., Van Linh, P., Nu, PA., Thi, H.D., Muller-Myhsok, B., Buss, H. and Tannich, E. (2002) Epidemiology of amebiasis in a region of high incidence of amebic liver abscess in central Vietnam. Am. J. Trop. Med. Hyg., 66(5): 578-583.

73. Leone, M., Honstettre, A., Lepidi, H., Capo, C., Bayard, F., Raoult, D. and Mege, J. (2004) Effect of sex on Coxiella burnetii infection: Protective role of 17b-estradiol. J. Infect. Dis., 189(2): 339-345.

74. Pasche, B., Kalaydjiev, S., Franz, T.J., Kremmer, E., GailusDurner, V., Fuchs, H., de Angelis, M.H., Lengeling, A. and Busch, D.H. (2005) Sex-dependent susceptibility to Listeria monocytogenes infection is mediated by differential interleukin-10 production. Infect. Immun., 73(9): 5952-5960.

75. Hertz, D., Dibbern, J., Eggers, L., von Borstel, L. and Schneider, B.E. (2020) Increased male susceptibility to Mycobacterium tuberculosis infection is associated with smaller B cell follicles in the lungs. Sci. Rep., 10(1): 5142.

76. Gomes, C.K., Guedes, M.S., Dellagostin, O., Potula, H.H. and Gomes-Solecki, M. (2018) Lethality of Leptospirosis Depends on Sex: Male Hamsters Succumb to Infection with Lower Doses of Pathogenic Leptospira. https://www. researchgate.net/publication/325163946. Retrieved on 6-11-2020.

77. Bandara, M., Ananda, M., Wickramage, K., Berger, E. and Agampodi, S. (2014) Globalization of leptospirosis through travel and migration. Global Health, 10(1): 61.

78. Goris, M.G.A. (2016) Leptospirosis: Epidemiology, Clinical Aspects and Diagnosis. Ph.D. Thesis Prepared at KIT Biomedical Research. KIT, Koninklijk Instituut Voor de Tropen/Royal Tropical Institute, Netherlands.

79. Tangkanakul, W., Smits, H.L., Jatanasen, S. and Ashford, D.A. (2005) Leptospirosis: An emerging health problem in Thailand. Southeast Asian J. Trop. Med. Public Health, 36(2): 281-288.

80. Beckel, N.F., O'Toole, T.E., Rozanski, E.A. and Labato, M.A. (2005) Peritoneal dialysis in the management of acute renal failure in 5 dogs with leptospirosis. Vet. Emerg. Crit. Care, 15(3): 201-205.

81. Knopfler, S., Mayer-Scholl, A., Luge, E., Klopfleisch, R., Gruber, A.D., Nöckler, K. and Kohn, B. (2017) Evaluation of clinical, laboratory, imaging findings and outcome in 99 dogs with leptospirosis. JSAP, 58(10): 582-588.

82. Ghasemian, R., Shokri, M., Makhlough, A. and SurakiAzad, M.A. (2016) The course and outcome of renal failure due to human leptospirosis referred to a hospital in North of Iran., A follow-up study. Caspian J. Intern. Med., 7(1): 7-12.

83. Hounkpatin, H.O., Fraser, S.D.S., Glidewell, L., Blakeman, T., Lewington, A. and Roderick, P.J. (2019) Predicting risk of recurrent acute kidney injury: A systematic review. Nephron, 142(2): 83-90.
84. Fouts, D.E., Matthias, M.A., Adhikarla, H., Adler, B., Amorim-Santos, L., Berg, D.E., Bulach, D., Buschiazzo, A., Chang, Y.F., Galloway, R.L., Haake, D.A., Haft, D.H., Hartskeerl, R., Ko, A.I., Levett, P.N., Matsunaga, J., Mechaly, A.E., Monk, A.M., Nascimento, A.L.T., Nelson, K.E., Palsson, B., Peacock, S.J., Picardeau, M., Ricaldi, J.N., Thaipandungpanit, J., Wunder, E.A. Jr., Yang, X.F., Zhang, J.J. and Vinetz, J.M. (2016) What makes a bacterial species pathogenic?: Comparative genomic analysis of the genus Leptospira. PLoS Negl. Trop. Dis., 10(2): e0004403.

85. Philip, N., Affendy, N.B., Ramli, S.N.A., Arif, M., Raja P., Nagandran, E., Renganathan, P. and Neela, V.K. (2020) Leptospira interrogans and Leptospira kirschneri are the dominant Leptospira species causing human leptospirosis in central Malaysia. PLoS Negl. Trop. Dis., 14(3): e0008197.

86. Chang, M.Y., Cheng, Y.C., Hsu, S.H., Ma, T.L., Chou, L.F., Hsu, H.H., Tian, Y.C., Chen, Y.C., Sun, Y.J., Hung, C.C., Pan, R.L. and Yang, C.W. (2016) Leptospiral outer membrane protein LipL32 induces inflammation and kidney injury in zebrafish larvae. Sci. Rep., 9(6): 27838.

87. Abdulkader, R.C. and Silva, M.V. (2008) The kidney in leptospirosis. Pediatr. Nephrol., 23(12): 2111-2120.

88. Vihol, P.D., Patel, J.M., Patel, J.H., Prasad, M.C., Kalyani, I.H. and Brahmkshtri, B.P. (2016) Caprine leptospirosis: Hematobiochemical and urinalyses studies. Vet. World, 9(3): 337-341

89. Budihal, S.V. and Perwez, K. (2014) Leptospirosis diagnosis: Competancy of various laboratory tests. J. Clin. Diag. Res., 8(1): 199-202.

90. Rojas, P., Monahan, A.M., Schuller, S., Miller, I.S., Markey, B.K. and Nally, J.E. (2010) Detection and quantification of leptospires in urine of dogs: A maintenance host for the zoonotic disease leptospirosis. Eur. J. Clin. Microbiol. Infect. Dis., 29(10): 1305-1309.

91. Yang, C.W. (2018) Leptospirosis renal disease: Emerging culprit of chronic kidney disease unknown etiology. Nephron, 138(2): 129-136.

92. Fanton d'Andon, M., Quellard, N., Fernandez, B., Ratet, G. and Lacroix-Lamande, S. (2014) Leptospira interrogans induces fibrosis in the mouse kidney through inos-dependent, TLR-and NLR-independent signaling pathways. PLoS Negl. Trop. Dis., 8(1): e2664.

93. Yener, Z. and Keles, H. (2001) Immunoperoxidase and histopathological examinations of leptospiral nephritis in cattle. J. Vet. Med. A, 48(7): 441-447.

94. Saglam, Y.S., Temur, A. and Aslan, A. (2003) Detection of leptospiral antigens in kidney and liver of cattle. Dtsch. Tierärztl. Wochenschr., 110(2): 75-77.

95. Sitprija, V., Losuwanrak, K. and Kanjanabuch, T. (2003) Leptospiral nephropathy. Semin. Nephrol., 23(1): 42-48. 